\title{
Strains of the toxic and bloom-forming Nodularia spumigena (cyanobacteria) can degrade methylphosphonate and release methane
}

\author{
Jonna E. Teikari $\mathbb{D}^{1} \cdot$ David P. Fewer $\mathbb{D}^{1} \cdot$ Rashmi Shrestha ${ }^{1} \cdot$ Shengwei Hou $\mathbb{D}^{2} \cdot$ Niina Leikoski ${ }^{1} \cdot$ Minna Mäkelä $^{3}$. \\ Asko Simojoki ${ }^{3} \cdot$ Wolfgang R. Hess $\mathbb{( D}^{2} \cdot$ Kaarina Sivonen $\mathbb{1}^{1}$
}

Received: 30 June 2017 / Revised: 8 January 2018 / Accepted: 10 January 2018 / Published online: 14 February 2018

(c) The Author(s) 2018. This article is published with open access

\begin{abstract}
Nodularia spumigena is a nitrogen-fixing cyanobacterium that forms toxic blooms in the Baltic Sea each summer and the availability of phosphorous is an important factor limiting the formation of these blooms. Bioinformatic analysis identified a phosphonate degrading $(p h n)$ gene cluster in the genome of $N$. spumigena suggesting that this bacterium may use phosphonates as a phosphorus source. Our results show that strains of $N$. spumigena could grow in medium containing methylphosphonic acid (MPn) as the sole source of phosphorous and released methane when growing in medium containing MPn. We analyzed the total transcriptomes of $N$. spumigena UHCC 0039 grown using MPn and compared them with cultures growing in $\mathrm{P}_{\mathrm{i}}$-replete medium. The $p h n J$, phosphonate lyase gene, was upregulated when MPn was the sole source of phosphorus, suggesting that the expression of this gene could be used to indicate the presence of bioavailable phosphonates. Otherwise, growth on MPn resulted in only a minor reconstruction of the transcriptome and enabled good growth. However, N. spumigena strains were not able to utilize any of the anthropogenic phosphonates tested. The phosphonate utilizing pathway may offer $N$. spumigena a competitive advantage in the $\mathrm{P}_{\mathrm{i}}$-limited cyanobacterial blooms of the Baltic Sea.
\end{abstract}

\section{Introduction}

Phosphorus is an essential macronutrient for life, being a key component in organic biomolecules, such as DNA, proteins, and phospholipids. The most preferable form of phosphorus for the uptake by cyanobacteria is orthophosphate ions $\mathrm{H}_{2} \mathrm{PO}_{4}{ }^{2-}, \mathrm{HPO}_{4}{ }^{2-}$, and $\mathrm{PO}_{4}{ }^{3-}\left(\mathrm{P}_{\mathrm{i}}\right)$, which occur

Electronic supplementary material The online version of this article (https://doi.org/10.1038/s41396-018-0056-6) contains supplementary material, which is available to authorized users.

$\triangle$ Kaarina Sivonen

Kaarina.sivonen@helsinki.fi

1 Department of Microbiology, University of Helsinki, Viikinkaari 9, Helsinki FI-00014, Finland

2 Genetics and Experimental Bioinformatics, Institute of Biology III, University Freiburg, Schänzlestraße 1, Freiburg D-79104, Germany

3 Department of Agricultural Sciences, University of Helsinki, Viikinkaari 9, Helsinki FI-00014, Finland at an oxidation state of +5 in nature and these orthophosphates dominate the pool of dissolved inorganic phosphorus (DIP) [1]. Dissolved organic phosphorus (DOP) comprises another pool of phosphorus in the water ecosystems and includes two important bond classes, ester (C$\mathrm{O}-\mathrm{P})$ and carbon-phosphorus (C-P) bonds. Phosphoesters are degraded by alkaline phosphatase and measurement of alkaline phosphatase activity has been used generally as an indicator for $\mathrm{P}_{\mathrm{i}}$ deficiency [2, 3] (Van Wambeke et al. 2002). Organic phosphonates, derivatives of phosphorus acid where the phosphorus is at the oxidation state of +3 , are poorly studied even though they have proposed to constitute up to $25 \%$ of the total DOP pool in the oceans [4-6]. Many of the phosphonates in the DOP pool are natural metabolites but some have an anthropogenic origin [7-9]. Phosphonates are recalcitrant to degradation, due to the presence of the C-P bond, and are generally thought to particulate and sediment [1].

$P_{i}$ is usually found at very low concentrations in environment and therefore lack of $P_{i}$ is the main growth-limiting factor for nitrogen-fixing and phototrophic cyanobacteria during blooms in aquatic ecosystems [10-12]. Bacteria have 
Table 1 Nodularia spumigena -specific primers used in this study

\begin{tabular}{|c|c|c|c|c|c|c|}
\hline Target gene & Annotation & Primer & Sequence $5^{\prime}->3^{\prime}$ & Product size (bp) & Efficiency (\%) & $\begin{array}{l}\text { Melting temperature }\left({ }^{\circ}\right. \\
\text { C) }\end{array}$ \\
\hline \multirow[t]{2}{*}{ phnD } & \multirow{2}{*}{$\begin{array}{l}\text { Phosphonate } \\
\text { transporter }\end{array}$} & phnDF & GGTGCCTGCGGATTCTGACA & \multirow[t]{2}{*}{225} & \multirow[t]{2}{*}{98.8} & 63 \\
\hline & & phnDR & TAACATCGCCGCGTCATGAG & & & 60 \\
\hline \multirow[t]{2}{*}{ phnJ } & \multirow[t]{2}{*}{ C-P bond lyase } & phnJF & TTCTAGGGCGTGCATTTTGC & \multirow[t]{2}{*}{216} & \multirow[t]{2}{*}{99.6} & 58 \\
\hline & & phnjJR & ACCAACGCCGTGAATATTCG & & & 58 \\
\hline \multirow[t]{2}{*}{ pstS } & \multirow[t]{2}{*}{ Phosphate binding } & pstSF & GTTGCAGCCAATGGCACT & \multirow[t]{2}{*}{119} & \multirow[t]{2}{*}{99.3} & 56 \\
\hline & & pstSR & CTTGACTTGTGCCAAACC & & & 54 \\
\hline \multirow[t]{2}{*}{ gyrB } & \multirow[t]{2}{*}{ Gyrase subunit B } & gyrBF & CGCATATTCGCACACTGTTG & \multirow[t]{2}{*}{189} & \multirow[t]{2}{*}{100.5} & 58 \\
\hline & & gyrBR & TGTTGTAGTTGGCGTTGCTG & & & 58 \\
\hline
\end{tabular}

evolved specific strategies to enhance phosphorus availability under $\mathrm{P}_{\mathrm{i}}$-limited conditions [13, 14]. The highaffinity phosphate transport system, encoded in the pstABCS operon, is the most studied system for $\mathrm{P}_{\mathrm{i}}$ uptake. The pstABCS operon belongs to the pho regulon, which is activated by autophosphorylation when the $\mathrm{P}_{\mathrm{i}}$ concentration is low [15-17]. The PstABCS complex thus ensures rapid and effective scavenging of $\mathrm{P}_{\mathrm{i}}$ in phosphorus-limiting conditions.

Many heterotrophic bacteria possess a phosphonate degrading $(p h n)$ gene cluster required for transport and assimilation of phosphonates that enables them to cope better with DIP-limited conditions by allowing them to use phosphonates as a source of phosphorus [18, 19]. The phn gene cluster is also part of the pho regulon and it consists of a phosphonate transporter complex $(p h n C-E)$ and the multisubunit C-P lyase complex (phnG-P), which cleaves the C$\mathrm{P}$ bond in phosphonates [20-22]. The PhnN, PhnO, and $\mathrm{PhnP}$ proteins are not required for $\mathrm{C}-\mathrm{P}$ bond cleavage but they most probably have a role as accessory proteins or regulators [23]. The PhnF protein acted as a repressor of phnC-E in Mycobacterium smegmatis [24]. The cyanobacteria Trichodesmium IMS101, Synechococcus JA-2-3Ba (2-13), and Anabaena cylindrica PCC 7122 have been found to harbor full phn gene clusters including phosphonate transport and C-P lyase units, and can grow in medium containing phosphonates as a sole source of phosphorus [25-27]. These cyanobacteria contribute to methane supersaturation in the epipelagic zone of marine ecosystems through the degradation of MPn thus releasing methane into the surrounding environment [28, 29]. The MPn cycle may partially explain the oceanic methane paradox, where methane concentration in the surface waters is above the atmospheric equilibrium [4].

The diazotrophic cyanobacteria Nodularia spumigena, Aphanizomenon spp., and Dolichospermum spp. form annual toxic blooms in the Baltic Sea [30-32] despite low $\mathrm{P}_{\mathrm{i}}$ concentrations $(0.1-0.01 \mu \mathrm{M})[33,34]$. N. spumigena utilizes alternative phosphorus sources by degrading organophosphates using alkaline phosphatases [35]. However, the presence of a phn gene cluster in the genome of $N$. spumigena CCY 9414 suggested that this strain might be able to degrade and use phosphonates as an alternative source of phosphorous [36]. Supersaturation of methane has been detected in the surface waters of the Baltic Sea with great temporal variation [37]. Elevated methane concentration in the surface water was measured during the summer and early autumn coincidental with $N$. spumigena bloom formation [37, 38]. The aerobic release of the methane as a byproduct of MPn degradation could explain the reported peaks in methane concentration in the Baltic Sea $[37,38]$. Here, we studied the capacity of axenic Baltic Sea N. spumigena strains isolated from the Baltic Sea to utilize phosphonates as the sole source of phosphorus and their ability to simultaneously release methane. We analyzed the expression of phosphonate transporter ( $p h n D)$, phosphonate lyase $(p h n J)$, and high-affinity phosphate transporter ( $p s t S)$ genes of two Baltic Sea N. spumigena UHCC 0039 and 0060 strains and sequenced total transcriptomes of the cells growing in medium with MPn as a sole source of phosphorus and compared them with cells growing in the medium with $\mathrm{P}_{\mathrm{i}}$. N. spumigena strains had the ability to degrade some phosphonates, which could represent an alternative source of phosphorus under $\mathrm{P}_{\mathrm{i}^{-}}$ limiting conditions in the Baltic Sea. N. spumigena cyanobacteria released methane when MPn was present in the growth medium and the use of MPn as the sole source of phosphorus resulted in only a minor reconstruction of the transcriptome enabling good growth of $N$. spumigena.

\section{Materials and methods}

\section{Screening for phnJ genes}

The BlastP algorithm was used to identify PhnJ phosphonate lyase proteins from cyanobacterial genomes using the PhnJ sequences from Escherichia coli (E. coli) K12 and $N$. 
spumigena UHCC 0039 as queries. Genomes encoding the PhnJ protein were downloaded from the NCBI genome database (Table S1). The gene order of the phn gene cluster was determined using the Artemis genome browser [39]. A total of 16 strains of the genus Nodularia were selected for the screening for the occurrence and distribution of phosphonate lyase $(p h n J)$ and transporter $(p h n D)$ genes (Table S2). phnJ, phnD, and pstS primers were designed based on the known N. spumigena UHCC 0039 (NCBI accession number, PRJNA352241), CCY 9414 sequences (NCBI accession number, PRJNA13447), and CENA 596 (NCBI accession number, PRJNA315832) (Table 1). $N$. spumigena-specific primers were also used to amplify phnJ and $p h n D$ genes from environmental DNA samples collected after cyanobacterial blooms in August 2016 (Table S3). Genomic DNA was isolated from the cyanobacterial cultures listed in Table S2 using the E.Z.N.A ${ }^{\circledR}$ Plant DNA kit (Omega Biotek) and from environmental samples using AllPrep DNA/RNA mini kit (Qiagen). The PCR reaction mix $(20 \mu \mathrm{L})$ consisted of $100 \mathrm{ng}$ template genomic DNA, $750 \mathrm{nM}$ of both primers (Oligomer, Table 1), $2 \mu$ of $10 \times$ reaction buffer (Thermo Scientific), $200 \mu \mathrm{M}$ dNTP (Thermo Scientific) and 0.4 U Dynazyme II (Thermo Scientific) in a total volume of $20 \mu \mathrm{L}$. Purified water was used as a template in negative controls. The PCR cycling parameters were as follows: $94^{\circ} \mathrm{C}$ for $3 \mathrm{~min}, 30 \times$ $\left(94{ }^{\circ} \mathrm{C}\right.$ for $30 \mathrm{~s}, 60.5^{\circ} \mathrm{C}$ for $30 \mathrm{~s}, 72^{\circ} \mathrm{C}$ for $180 \mathrm{~s}$ ) and $72{ }^{\circ} \mathrm{C}$ for $10 \mathrm{~min}$.

\section{Cyanobacterial strains and cultivation}

$N$. spumigena strains UHCC 0039 (formerly named $N$. spumigena AV1) and UHCC 0060 (formerly named $N$. spumigena HEM) were isolated from the Gulf of Finland [32] and purified into axenic cultures (Table S1). The strains were maintained in continuous batch culture with Z8XS medium containing $17.1 \mathrm{mg} \mathrm{L}^{-1}$ of inorganic phosphate $\mathrm{P}_{\mathrm{i}}$, without nitrogen and under continuous illumination of 3.2-3.7 $\mu \mathrm{mol}$ photons $\mathrm{m}^{-2} \mathrm{~s}^{-1}$ [40]. Cultures were starved in phosphorus-free medium (Z8XS-P) for 7 days to deplete the intracellular phosphorus store . Cells, in three biological replicates, were harvested after starvation and transferred to fresh Z8XS-P medium containing either methylphosphonic acid (MPn) (Sigma-Aldrich), ethylphosphonic acid (EPn) (Sigma-Aldrich), 2-aminoethylphosphonic acid (2Apn) (Sigma-Aldrich), etidronic acid monohydrate (SigmaAldrich), $N$-(phophonomethyl) glycine (Sigma-Aldrich), nitrilotri(methylphosphonic acid) (Sigma-Aldrich) or 2-phosphonobutane-1,2,4-tricarboxylic acid (abcr $\mathrm{GmbH}$ ) as a source of phosphorus. The phosphorus concentration in each phosphonate medium was adjusted to be equal to the amount of phosphorus in the original Z8XS medium. Z8XS medium containing $\mathrm{P}_{\mathrm{i}}$ was used as a positive control to gain proper cellular proliferation and Z8XS-P medium lacking $\mathrm{P}_{\mathrm{i}}\left(-\mathrm{P}_{\mathrm{i}}\right)$ was used as a negative control. Cultures were grown under continuous illumination of $3.2-3.7 \mu \mathrm{mol}$ photons $\mathrm{m}^{-2} \mathrm{~s}^{-1}$ for 12 days. In all, $54 \mathrm{~mL}$ of the cultures were moved to $60 \mathrm{~mL}$ of fresh medium after 12 days of incubation and further cultured for $41 / 38$ days. All glassware was acid washed using $0.1 \mathrm{M}$ $\mathrm{HCl}$.

\section{Determination of chlorophyll $a$ concentration, alkaline phosphatase activity, and methane liberation}

Chlorophyll $a$ concentration and alkaline phosphatase activity were measured at 4-day intervals during the experiment. In all, $1 \mathrm{~mL}$ of culture was filtered through 21 $\mathrm{mm}$ glass microfiber filters $\mathrm{GF} / \mathrm{C}$ (pore size $1.2 \mu \mathrm{m}$ ) (GE HealthCare) and stored in $-80^{\circ} \mathrm{C}$ for chlorophyll $a$ measurements. Chlorophyll $a$ was extracted from the filters using $1 \mathrm{~mL}$ of $90 \%$ acetone for $24 \mathrm{~h}$ at $-20{ }^{\circ} \mathrm{C}$ and chlorophyll $a$ concentrations were determined by measuring absorbance at 664,647 , and $630 \mathrm{~nm}$. The chlorophyll $a$ concentration was calculated using the Jeffrey and Humphrey [41] equation. Alkaline phosphatase activity was determined fluorometrically using 4-umbelliferyl phosphate as a substrate (Sigma-Aldrich) and 4-methylbellifernoe as a standard (Sigma-Aldrich) [42]. Enzyme activity was inhibited by heating the culture to $100^{\circ} \mathrm{C}$ for $2 \mathrm{~min}$ and this was used as a zero sample in order to eliminate background levels caused by cyanobacterial photopigments. The methane emission rate was determined by transferring $2 \mathrm{~mL}$ of $N$. spumigena UHCC 0039 culture to $12 \mathrm{~mL}$ Exetainer ${ }^{\circledR}$ vials with Double Wadded Exetainer ${ }^{\circledR}$ Cap (Labco) in 47 replicates, which were incubated for $0-32 \mathrm{~h}$. In total, $2 \mathrm{~mL}$ samples of $N$. spumigena UHCC 0039 and UHCC 0060 cultures were also transferred to $12 \mathrm{~mL}$ Exetainer $^{\circledR}$ vials with Double Wadded Exetainer ${ }^{\circledR}$ Cap and incubated for 24 $h$ using the original cultivation conditions to measure the methane emission in different stages of the experiment. Methane release to gaseous environment was analyzed by the headspace technique as follows. Gas samples of 8 $\mathrm{mL}$ (at atmospheric pressure) were taken from the headspace with a polypropylene syringe attached to a hypodermic needle and injected into helium-flushed and preevacuated $3 \mathrm{~mL}$ vials. Gas concentrations $\left(\mathrm{cm}^{3} \mathrm{~m}^{-3}\right)$ were analyzed using an Agilent GC 7890 custom gas chromatograph equipped with thermal conductivity, flame ionization, and electron capture detectors [43].

\section{Reverse transcriptase-quantitative PCR (RT-qPCR) and RNA-sequencing}

Samples for transcriptomic studies were collected at days 0, 12 , and 24 from the cultures containing no phosphorus, $\mathrm{P}_{\mathrm{i}}$, 


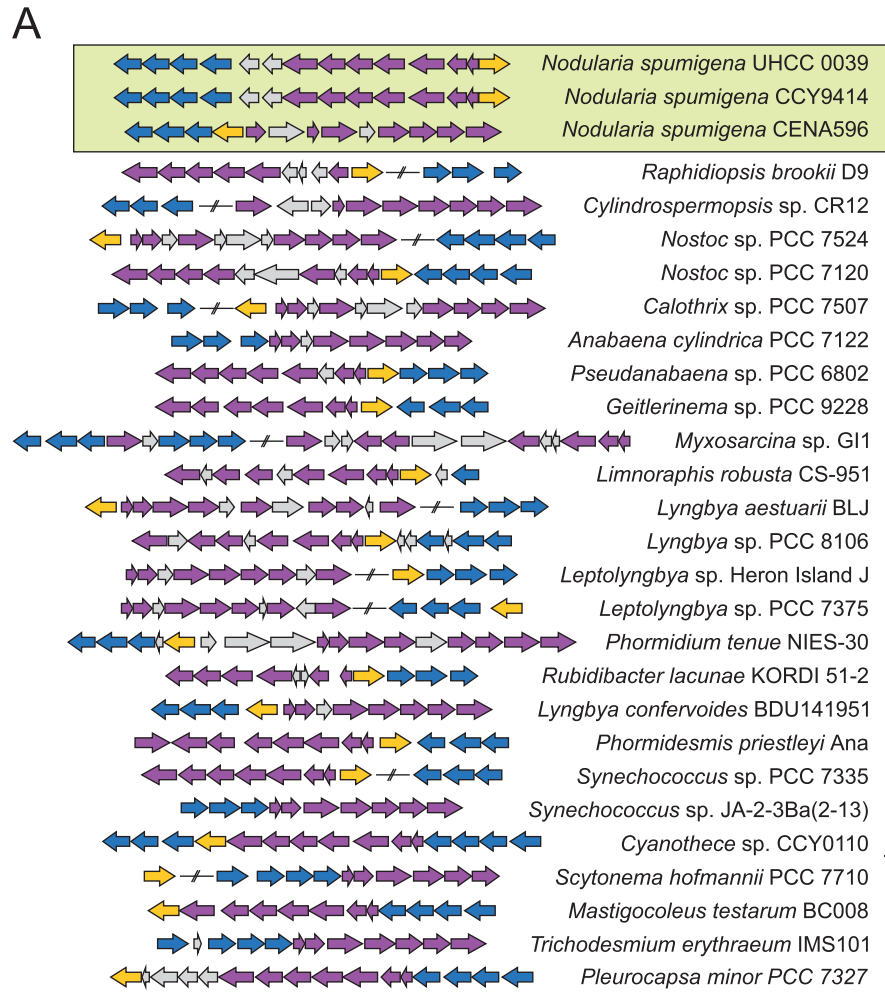

Fig. 1 Schematic presentation of phn gene clusters found from 28 sequenced cyanobacterial strains a. Annotated phn gene cluster of Nodularia spumigena UHCC 0039 located at 535027-547520 bp b. Screening for $p h n D$ (upper panel) and $p h n J$ (lower panel) genes from

MPn, and 2APn. RNA samples were fixed with a solution, containing $10 \%$ ethanol and $5 \%$ of phenol and filtered through a $0.22 \mu \mathrm{m}$ pore diameter polycarbonate filters (GE Water and Process Technologies). RNA was isolated from the filters using RNeasy mini kit (Qiagen) and genomic DNA was degraded using the TURBO DNA-free ${ }^{\text {TM }}$ kit (Life Technologies). Ribosomal RNA was removed using MICROBExpress ${ }^{\mathrm{TM}}$ Bacterial mRNA enrichment kit (Life Technologies) and complementary DNA (cDNA) libraries were prepared using Bacterial ScriptSeq Complete Kit (Illumina). Total transcriptomes of $N$. spumigena UHCC 0039 in control $\left(\mathrm{P}_{\mathrm{i}}\right)$ and MPn treatment on day 12 were sequenced in three replicates of control and in two replicates of treatment, at the Institute for Molecular Medicine Finland (FIMM). Paired-end Illumina HiSeq 2500 RNA-sequencing data were deposited under the accession number of PRJNA388731 and downstream data analysis was performed as described in supplementary information.

$N$. spumigena-specific primers were designed to amplify phnD, phnJ, pstS, and gyrB target genes (Table 1). The RTqPCR analysis was performed using a CFX96 qPCR device (Bio-Rad) and analyzed with the CFX Manager (Bio-Rad). The RT-qPCR reaction mix consisted of $10 \mathrm{ng}$ template cDNA, $300 \mathrm{nM}$ of both primers (Oligomer), and $10 \mu \mathrm{l}$ of Power Up ${ }^{\mathrm{TM}}$ SYBR Green Master Mix (Thermo Fisher Scientific) in a total volume of $20 \mu \mathrm{L}$. Purified water was

\section{B}

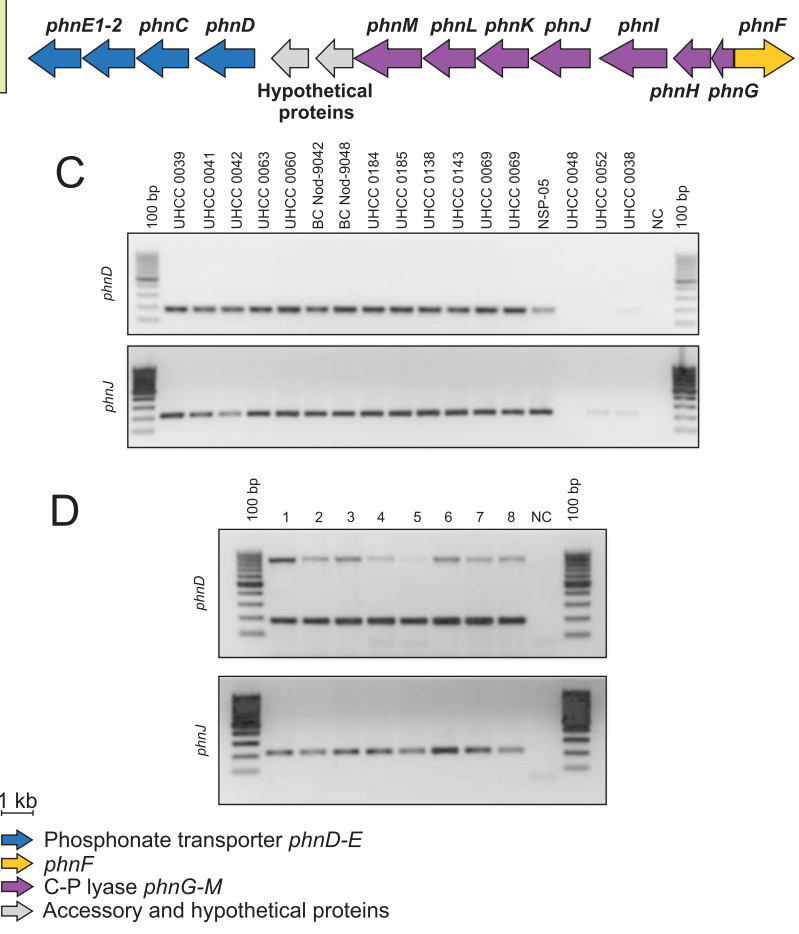

the Nodularia sp. cyanobacteria isolated from the Baltic Sea $\mathbf{c}$ and environmental samples from the Baltic Sea d. Detailed description of Nodularia sp. strains and environmental sampling points can be found from Tables S2 and S3

used as a negative control. The qPCR cycling parameters used were as follows: $95^{\circ} \mathrm{C}$ for $7 \mathrm{~min}, 40 \times\left(95^{\circ} \mathrm{C}\right.$ for $10 \mathrm{~s}$, $60.5^{\circ} \mathrm{C}$ for $30 \mathrm{~s}$ ) and $95^{\circ} \mathrm{C}$ for $10 \mathrm{~s}$. The annealing temperature for melting curve analysis was set from 65 to $95^{\circ} \mathrm{C}$ for $5 \mathrm{~s}$ to determine amplification of specific product. The amplification efficiency for each primer pair was calculated from the regression slope of standard curve (Figure S1). The relative gene expression was determined by ddCT method comparing values between gyrB and target genes $p h n J$, $p s t S$, and $p h n D$ in $\mathrm{P}_{\mathrm{i}},-\mathrm{P}_{\mathrm{i}}$ and treatments. Three technical replicates were used.

\section{Results}

\section{Distribution of phn gene cluster}

Bioinformatics analysis demonstrates that the phosphonate gene cluster is widely distributed in the cyanobacterial phylum (Fig. 1). A total of 27 out of 500 (5.4\%) sequenced cyanobacterial genomes in the NCBI database were found to encode complete or nearly complete sets of genes for phosphonate transport ( $p h n C-E$ ) and the C-P lyase complex (phnG-M) (Fig. 1a). The phn gene clusters lacked clear synteny and the size of the phn gene clusters ranged from 8 to $21 \mathrm{~kb}$ with the size variation due to gene deletions, 
Fig. 2 Growth a, b and alkaline phosphatase activity $\mathbf{c}, \mathbf{d}$ of $N$. spumigena UHCC 0039 (left panel) and UHCC 0060 (right panel) in the presence of phosphonates. $-\mathrm{P}_{\mathrm{i}}$ no phosphorus, $\mathrm{P}$ phosphate, MPn methylphosphonate, 2APn 2aimonmethylphosphonate, EPn ethylphosphonate
A
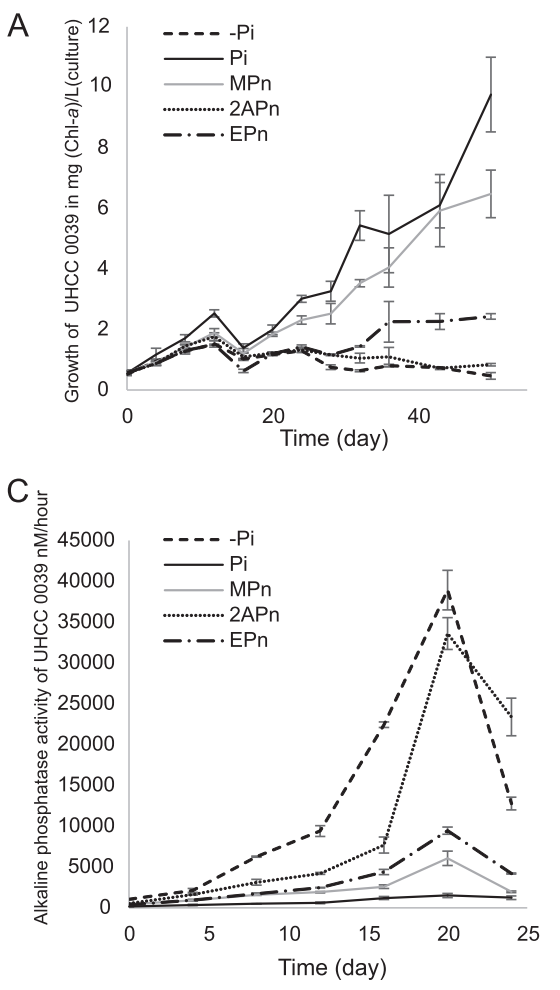

B
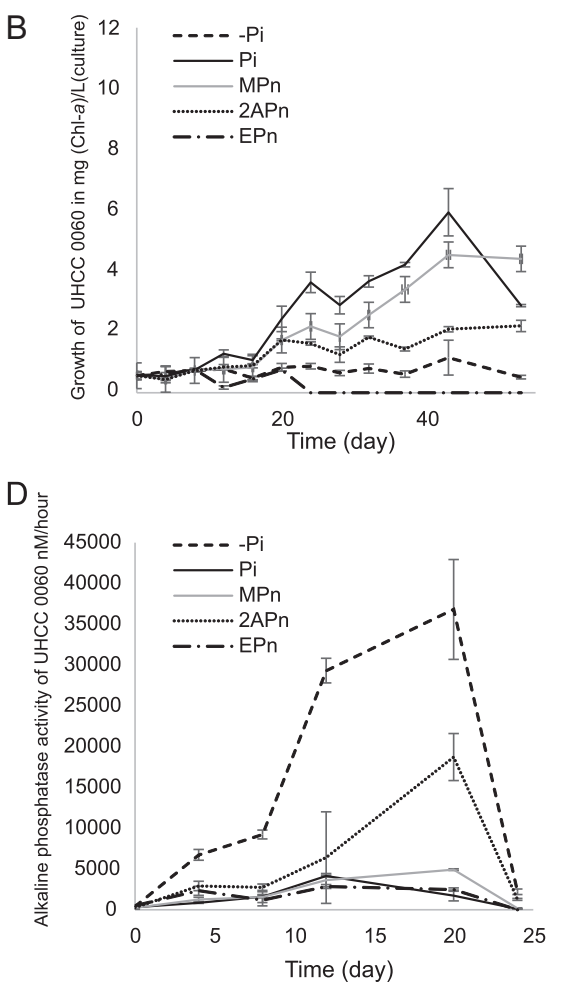

duplications, and accessory/hypothetical proteins located between core genes (Table S2). All three strains of $N$. spumigena, for which genome sequences are available, encoded the phn gene cluster (Fig. 1a). The phnJ and phnD genes were also common in $N$. spumigena strains but were absent from the other species of the Nodularia genus tested and from Aphanizomenon flos-aquae (Fig. $1 \mathrm{~b}$ and Table S2). We amplified phnD and phnJ genes from the environmental samples collected from the Baltic Sea using the N. spumigena-specific phnD and phnJ primers demonstrating that these genes are abundant in the Gulf of Finland and the Baltic Proper (Fig. 1c).

\section{Phosphonates as a sole source of phosphorus}

N. spumigena UHCC 0039 and UHCC 0060 were both able to grow in medium containing MPn (Figs. 2a, b). Minor growth was observed when $N$. spumigena UHCC 0039 grew in the presence of EPn and N. spumigena UHCC 0060 in the medium containing 2APn. None of the tested strains were able to utilize the anthropogenic phosphonates etidronic acid monohydrate, $N$-(phophonomethyl) glycine, nitrilotri(methylphosphonic acid), or 2-phosphonobutane1,2,4-tricarboxylic acid tested here. Maximal growth rates in studied conditions were obtained in the cultures growing in $\mathrm{P}_{\mathrm{i}}$ medium. Moreover, minor growth in $-\mathrm{P}_{\mathrm{i}}$ medium was measured indicating that they had not exhausted internal polyphoshphate stores (Figs. 2a, b).
Alkaline phosphatase activity was followed during the cultivation experiment. Alkaline phosphatase activity peaked in both strains in the negative control, when phosphorus was omitted from the medium (Figs. 2c, d). Remarkably elevated alkaline phosphatase activity was additionally observed in 2APn cultures but enzyme activity was reduced compared with $-\mathrm{P}_{\mathrm{i}}$ medium (Figs. 2c, d). Elevated alkaline phosphatase activity was not observed in MPn supplemented medium despite the absence of $P_{i}$ from the growth medium (Figs. 2c, d).

Degradation of phosphonates by the C-P lyase complex releases not only phosphate for the use of the cells but also the organic byproduct, e.g. methane. The rate of the methane flux from $N$. spumigena UHCC 0039 culture to the gaseous environment was determined to be $1.84 \mathrm{nmol} \mathrm{h}^{-1}$ per mg of chlorophyll $a$, while prevailing chlorophyll $a$ concentration in the culture was $2.4 \mathrm{mg} \mathrm{L}^{-1}$ (Fig. 3a). Release of methane was observed in cultures of both strains (Fig. 3b) but emission rate differed remarkably in different growth phases. Overall, N. spumigena UHCC 0060 seemed to release more methane compared $N$. spumigena UHCC 0039.

\section{Transcriptional remodeling}

MPn and 2APn conditions were selected to analyze the expression levels of phosphorus utilizing genes, compared against the phosphorus-replete condition $\left(\mathrm{P}_{\mathrm{i}}\right)$, with 

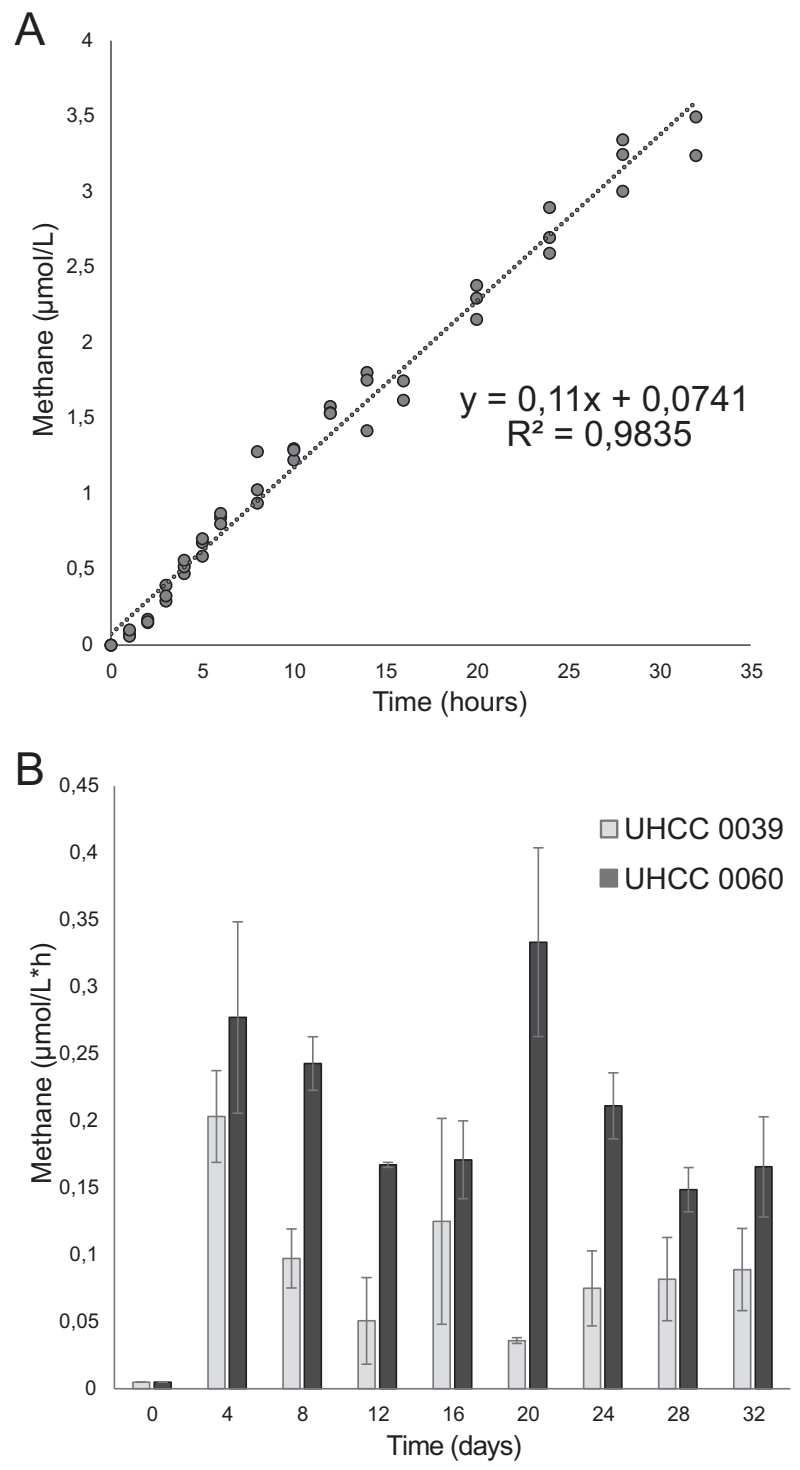

Fig. 3 Liberation of methane by N. spumigena UHCC 0039 in the medium containing MPn during $32 \mathrm{~h}$ a and amount of the methane release by $N$. spumigena UHCC 0039 and UHCC 0060 during the growth experiment $\mathbf{b}$. Based on the slope of cumulative methane release measurement a average methane release was determined to be $1.84 \mathrm{nmol} \mathrm{h}^{-1}$ per mg of chlorophyll $a$ while chlorophyll $a$ concentration was $2.4 \mathrm{mg} \mathrm{L}^{-1}$ in the culture

phosphorus-deplete condition $\left(-\mathrm{P}_{\mathrm{i}}\right)$ as the negative control. Specifically, the gene expression levels of $p h n D$, phnJ, and $p s t S$ were investigated in $N$. spumigena UHCC 0039 and UHCC 0060 using RT-qPCR. Although the C-P lyase complex is thought to belong to the pho regulon, the expression of $p h n J$ was upregulated only in the presence of MPn (Figs. 4). The phnJ gene was upregulated on day 12, in both MPn and 2APn conditions, whereas expression remained upregulated only in MPn treatment for 24 days. This provided further evidence that MPn was a suitable phosphorus source for the studied Baltic Sea $N$. spumigena cyanobacteria. The $p h n D$ gene was upregulated in $-\mathrm{P}_{\mathrm{i}}$ and
2APn conditions (Figs. 4). Upregulation of the phnD gene was minor in MPn treatment compared with $\mathrm{P}_{\mathrm{i}}$ treatments. Gene expression of $p s t S$ gene was additionally studied due to its suggested suitability as a marker for $P_{i}$ scarcity but in RT-qPCR analysis differences in $p s t S$ gene expression were not found (Figs. 4).

MPn was the only phosphonate tested that enabled good growth and proper cellular functioning of studied $N$. spumigena strains. We compared the transcriptomes of $N$. spumigena UHCC 0039 grown in MPn and normal $\mathrm{P}_{\mathrm{i}}$ conditions using RNA-Seq to unravel the transcriptomic responses of phosphonate treatment. In all, 84 upregulated and 8 downregulated genes were determined, by applying the false discovery rate cut-off of $<0.01$, accounting for a relatively small fraction of all genes $(1.8 \%)$. This provided further evidence that MPn permitted normal cellular functioning of $N$. spumigena UHCC 0039 (Fig. 5, Table 2, Table S4). The phn gene cluster in N. spumigena UHCC 0039 contains 14 genes, of which four (phnC-E12) are responsible for phosphonate transport, $p h n F$ acts as a regulator and phnG-M compose a complex cleaving the C-P bond (Fig. 1a). The two additional genes within the phn gene cluster of $N$. spumigena UHCC 0039 may be related to accessory or regulatory proteins. The C-P lyase complex (phnG-M) was heavily upregulated when phosphonate was present and was the strongest differentially expressed (DE) genomic region (Figs. 5a, b). Significant upregulation was also found for phnC-E12 and the two putative regulatory genes, but expression was more inconspicuous. The upstream region of the $p h n F$ gene was additionally highly expressed in MPn treatment, whereas expression of the coding region of phnF was weaker. By contrast, increased expression was found for the antisense strand of $p h n F$ in the $\mathrm{P}_{\mathrm{i}}$ control, suggesting an inhibitory role in gene regulation. The genome of $N$. spumigena UHCC 0039 contains also a secondary operon for phosphonate transport (phnC-E), which might be involved in the uptake of another forms of phosphorus, for example, organophosphates or phosphites. Transcription and upregulation of $p h n C$ and $p h n D$ in this secondary operon indicated that they could be functional (Table 2). Among the upregulated DE genes participating in phosphorus metabolism, high-affinity phosphate transport system pstABCS (Log2FC 0.99-2.1) and one atypical alkaline phosphatase phoA (BMF81_00431) together with hypothetical protein BMF81_00430, were upregulated (Table 2). Increased expression of pstABCS was unexpected, because upregulation of $p s t S$ was not found in the RT-qPCR study. This is most probably due to the different cDNA library protocols because initial transcriptome was the same and efficiency of the primers was high (Figure S1).

The MPn treatment seemed to co-induce an iron starvation response and upregulated genes related to lightharvesting complex of photosynthesis (Fig. 5, Table 2). 


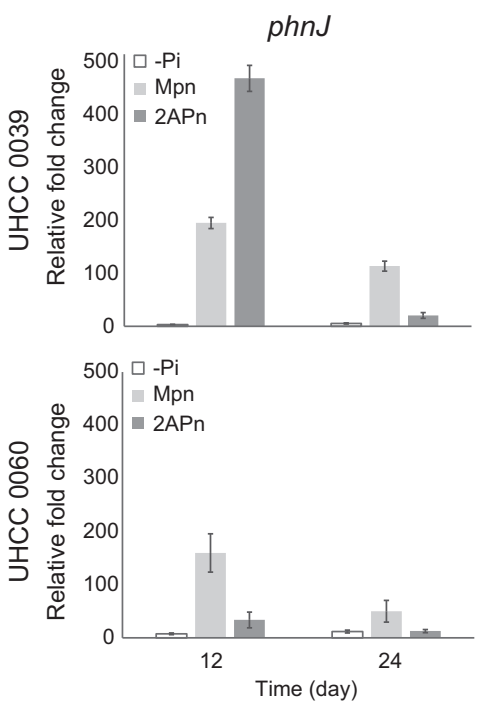

Fig. 4 Relative abundance of phnJ, phnD and pstS transcripts based on RT-qPCR analysis in $N$. spumigena UHCC 0039 (upper panel) and UHCC 0060 (lower panel) compared with $\mathrm{P}_{\mathrm{i}}$
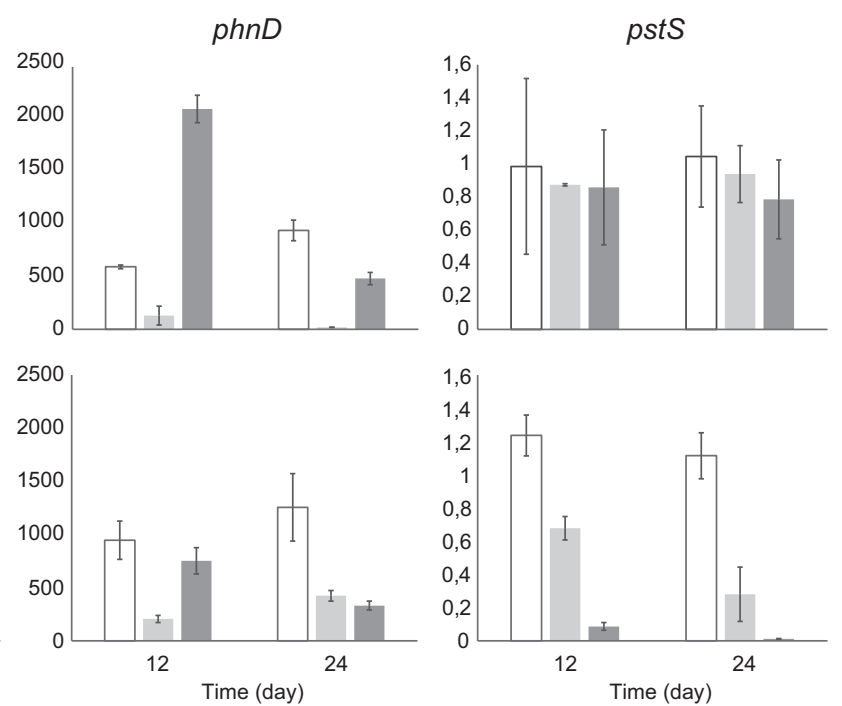

condition. - $\mathrm{P}_{\mathrm{i}}$ no phosphorus, MPn methylphosphonate, 2APn 2aimonmethylphosphonate. Note the different scales

However, Nodularia spumigena CCY 9414, isolated from the Baltic Sea, encodes a phn gene cluster indicating it could degrade phosphonates and liberate $\mathrm{P}_{\mathrm{i}}$ to meet cellular demand [36]. In this study we found $p h n D$ and $p h n J$, key genes of phn gene cluster, from all 12 investigated $N$. spumigena strains, as well as from two other previously sequenced N. spumigena CCY 9414 [36] and N. spumigena CENA 596 [48] strains showing that this gene cluster is common among $N$. spumigena (Fig. 1), but not in other Nodularia spp., Aphanizomenon flos-aquae or Dolichospermum spp. strains isolated from the Baltic Sea (Fig. 1b, unpublished data). The phn gene cluster was additionally found to be ubiquitous in the Baltic Sea using $N$. spumigena-specific primers probing environmental samples (Fig. 1c). Our bioinformatics analysis further showed that only $5.4 \%$ of the sequenced cyanobacteria deposited in GenBank carry this particular genetic region and the lack of clear synteny indicates that cyanobacteria have acquired the phn gene cluster by horizontal gene transfer. This has also been demonstrated by phylogenetic analyses of phnJ gene [26, 49]. The sporadic distribution of the phn gene cluster within the cyanobacterial phylum has also been described earlier [50]. This study confirms the hypothesis that $N$. spumigena could degrade phosphonates to cope with the lack of available $\mathrm{P}_{\mathrm{i}}$ in the Baltic Sea during summer [36] (Nausch, 1998) and may provide $N$. spumigena an important competitive advantage through utilization of phosphonates as an alternative source of phosphorus.

Previous studies have shown that cyanobacteria harboring phosphonate transport and C-P lyase units of the phn gene cluster can exploit a broad range of phosphonates such as 

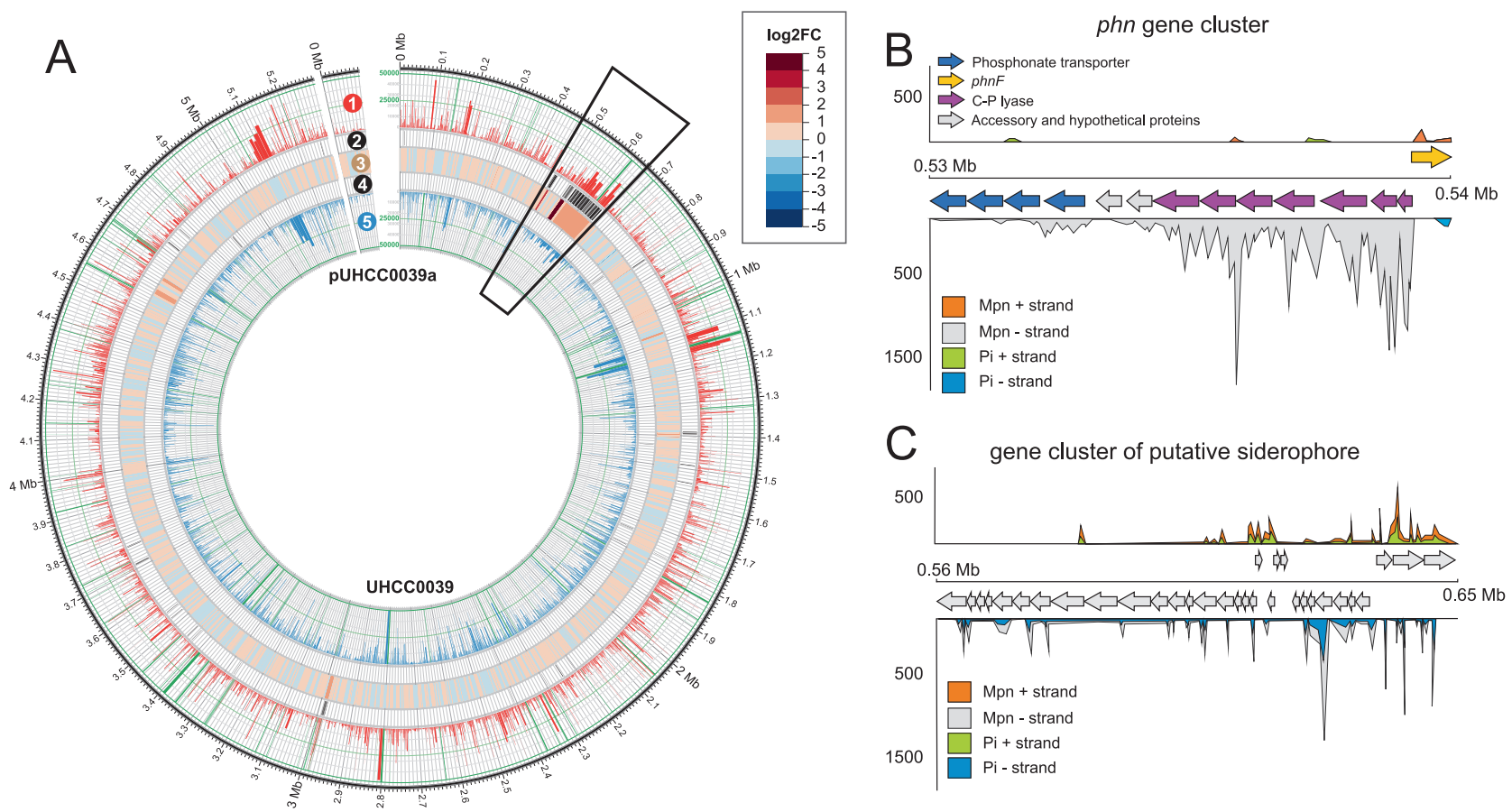

Fig. 5 Circular presentation of the N. spumigena UHCC 0039 genome along with illustration of RNA-seq data $\mathbf{a}$ and schematic zoom-in figures of phn gene cluster $\mathbf{b}$ and putative siderophore gene cluster $\mathbf{c}$. The rings of the circos plot from outermost to innermost. (1) mean per gene read count of sample grown in MPn condition, (2) upregulated

methyl- and ethylphosphonates, 2-aminoethylphosphonate and glyphosate [27, 28]. The majority of these strains comprise also the regulatory gene $p h n F$ despite $p h n F$ is missing from Trichodesmium erythraeum IMS101 and Synechococcus sp. JA-2-3BA(2-13). However, both strains are nevertheless capable of degrading phosphonates $[25,26]$. The small pore size of the PhnC-E channel and intracellular location of C-P lyase complex may be the reasons for limited utilization of phosphonate substrates. Furthermore, variations in amino-acid composition of $\mathrm{PhnD}$ proteins affecting the dissociation constants to different phosphonates [51] can also limit the usage of phosphonates. The phn gene cluster is thus not sufficient alone to confer the capacity to degrade phosphonates and physiological studies are needed to complement the genomics data to answer the question, which phosphonates are suitable for cyanobacteria.

Here we examined the growth of $N$. spumigena strains UHCC 0039 and UHCC 0060 carrying the phn gene cluster in seven different phosphonate supplemented media. MPn fulfilled the phosphorus demand in both strains and 2aminoehtylphosphonate acted as phosphorus source for $N$. spumigena UHCC 0039 and ethylphosphonic acid to $N$. spumigena UHCC 0060 but two latter substrates enabled only minor growth. Our results suggest that the Baltic Sea $N$. spumigena cyanobacteria can exploit naturally produced phosphonates among which MPn was the preferred form. differentially expressed genes, (3) $\log 2 \mathrm{FC}$ heat map, (4) downregulated differentially expressed genes, and (5) mean per gene read count of sample $\mathrm{P}_{\mathrm{i}}$. A maximum read count of 50,000 was set on rings (1) and (5) for visualization purpose. $\log 2 \mathrm{FC}=2$ times logarithmic fold change

MPn is suggested to be produced in oceans by heterotrophic microbes expressing a MpnS-dependent biosynthetic pathway [8] and liberation of MPn to the surrounding environment was estimated to be significant due to the short life cycle of these microbes [8]. MPn may thus serve as a phosphorous reservoir for cyanobacteria capable to C-P bond cleavage and this character may explain more intensive occurrence of $N$. spumigena compared with other diazotrophic cyanobacteria when inorganic phosphorus is absent from the upper water layers.

MPn is additionally a precursor for aerobic methane release [29] and circulation of MPn in the oceans is an important contributor in the methane flux to the atmosphere [4]. Based on our results, blooms of $N$. spumigena may also have an important role in aerobic methane release and explain temporal variation of the methane concentration in the Baltic Sea [37, 38]. In addition, phosphonates may increase $\mathrm{N}_{2}$-fixation in $\mathrm{P}_{\mathrm{i}}$-limited environment because $\mathrm{N}_{2}$ fixation positively correlates with phosphorus availability $[34,46,52,53]$. Flux of organic nitrogen to water body [11] further enhance eutrophication in water ecosystems [54]. Finally, nutrient-replete conditions also increase toxin production in $N$. spumigena (Lehtimäki et al. 1997). The anthropogenic phosphonates used in this study were not suitable phosphorus sources for studied $N$. spumigena strains and the riverine load of anthropogenic phosphonate 
Table 2 Selected differentially expressed genes of Nodularia spumigena UHCC 0039 while growing in medium containing methylphosphonate as a sole phosphorus source

\begin{tabular}{|c|c|c|c|c|}
\hline $\begin{array}{l}\text { Gene } \\
\text { name }\end{array}$ & Function & locus_tag & $\log 2 \mathrm{FC}^{*}$ & $p$-Value \\
\hline \multicolumn{5}{|c|}{ Phosphorus metabolism } \\
\hline pstA & High-affinity phosphate transporter & BMF81_03296 & 1.387 & $5.208 \mathrm{e}-06$ \\
\hline pstB & High-affinity phosphate transporter & BMF81_03295 & 0.831 & $4.261 \mathrm{e}-05$ \\
\hline$p s t C$ & High-affinity phosphate transporter & BMF81_03297 & 1.546 & $2.626 \mathrm{e}-06$ \\
\hline pst $S$ & High-affinity phosphate transporter & BMF81_03298 & 2.165 & $6.868 \mathrm{e}-08$ \\
\hline phnC2 & Phosphonate $\mathrm{ABC}$-transporter & BMF81_03014 & 0.907 & $1.108 \mathrm{e}-04$ \\
\hline phnD2 & Phosphonate $\mathrm{ABC}$-transporter & BMF81_03015 & 0.769 & $3.924 \mathrm{e}-05$ \\
\hline & Hypothetical protein & BMF81_00430 & 2.575 & $1.334 \mathrm{e}-06$ \\
\hline phoA & Alkaline phosphatase & BMF81_00431 & 3.607 & $3.972 \mathrm{e}-07$ \\
\hline \multicolumn{5}{|l|}{ Photosynthesis } \\
\hline $\mathrm{pbsC1}$ & Chlorophyll a/b binding light-harvesting protein & BMF81_02614 & 1.542 & $3.072 \mathrm{e}-05$ \\
\hline pbsC2 & Chlorophyll a/b binding light-harvesting protein & BMF81_02616 & 1.570 & $1.752 \mathrm{e}-05$ \\
\hline & Flavodoxin, chain A & BMF81_02618 & 1.642 & $5.378 \mathrm{e}-06$ \\
\hline & Hypothetical protein & BMF81_02619 & 1.486 & $1.715 \mathrm{e}-05$ \\
\hline pbsC3 & Chlorophyll a/b binding light-harvesting protein & BMF81_02620 & 1.768 & $8.771 \mathrm{e}-06$ \\
\hline pbsC4 & Chlorophyll a/b light-harvesting protein & BMF81_02622 & 1.967 & $1.106 \mathrm{e}-06$ \\
\hline & Plastocyanin & BMF81_00249 & 0.996 & $1.400 \mathrm{e}-04$ \\
\hline \multicolumn{5}{|l|}{ Iron uptake } \\
\hline & Regulatory protein & BMF81_03100 & 1.222 & $2.128 \mathrm{e}-06$ \\
\hline & TonB-dependent receptor & BMF81_01155 & 1.435 & $1.970 \mathrm{e}-05$ \\
\hline & TonB-dependent receptor & BMF81_01958 & 0.881 & $3.238 \mathrm{e}-05$ \\
\hline & $\begin{array}{l}\text { ABC-type } \mathrm{Fe} 3+\text {-siderophore transport system } \\
\text { permease component }\end{array}$ & BMF81_01159 & 1.140 & $1.782 \mathrm{e}-05$ \\
\hline & $\begin{array}{l}\text { ABC-type } \mathrm{Fe} 3+\text {-siderophore transport system } \\
\text { permease component }\end{array}$ & BMF81_01160 & 1.020 & $4.858 \mathrm{e}-05$ \\
\hline & $\begin{array}{l}\text { ABC-type } \mathrm{Fe} 3+\text {-siderophore transport system } \\
\text { permease component }\end{array}$ & BMF81_01161 & 1.215 & $3.983 \mathrm{e}-06$ \\
\hline & Hypothetical protein & BMF81_01162 & 1.053 & $2.535 \mathrm{e}-04$ \\
\hline
\end{tabular}

* Log2 fold change

compounds most probably does not enhance $N$. spumigena blooms in the Baltic Sea ([55], this study). However, light intensity used was low compared with conditions $N$. spumigena encounter in the environment [56] although it is likely that $N$. spumigena experience such low light conditions also in nature. Low light conditions resulted in relatively long doubling times of the cultures. In spite of this, studied $N$. spumigena strains were able to grow in MPn medium and release methane.

Genes assisting cyanobacteria to cope with phosphoruslimited conditions belong to the pho regulon, which are activated by $\mathrm{P}_{\mathrm{i}}$ scarcity. One widely used marker for detecting the activation of pho regulon and further $\mathrm{P}_{\mathrm{i}}$ scarcity is alkaline phosphatase activity. In our study, alkaline phosphatase activity decreased in both MPn and 2APn conditions compared with $-\mathrm{P}_{\mathrm{i}}$ condition. MPn did not induce alkaline phosphatase activity despite the lack of $\mathrm{P}_{\mathrm{i}}$, indicating an alternative phosphorus uptake pathway might be dominating the process. The phn gene cluster belongs to the pho regulon $[16,26]$ and thus should be induced in the lack of $\mathrm{P}_{\mathrm{i}}$. The C-P lyase part of the phn gene cluster was heavily upregulated in the presence of MPn, whereas upregulation of phosphonate transport system was slighter. RT-qPCR studies further validated that $p h n D$ gene was upregulated in $2 \mathrm{APn}$ and $-\mathrm{P}_{\mathrm{i}}$ control but constant upregulation of phnJ gene required suitable phosphonate substrate. Due to the bipartite structure of the phn gene cluster, $p h n D$ $E$ is most probably regulated independently and the role of $p h n F$ for the regulation of phnC-E may be crucial [24]. In addition, phnJ gene was found to be expressed only in the presence of suitable substrate (MPn). Chemical detection of phosphonates in saline water ecosystems is challenging and requires specific analytic tools (nuclear magnetic resonance spetroscopy, NMR) [4]. Thus, transcripts of phnJ gene may 
be suitable indicator for phosphonate bioavailability. Other genes of the pho regulon, such as the PstABCS system, were additionally upregulated in MPn condition showing that even though a suitable phosphorus source was available, the pho regulon remained activated.

Growth in MPn had little effect on the transcriptome of $N$. spumigena UHCC 0039. However, the treatment resulted in the co-induction of genes related to the lightharvesting complex, as well as iron starvation and acquisition. Expression of the genes encoding photopigments are sensitive to environmental changes and fine tuning the pool of photopigments is an important way for cyanobacteria in adapting to new environment [57]. The iron scarcity marker gene isiA becomes usually highly expressed under iron starvation [44]. The isiA gene in $N$. spumigena is located together with genes encoding CP43/Pcb family proteins [36] and in our study the whole locus was heavily upregulated in the presence of MPn. Siderophore-mediated iron uptake in cyanobacteria is one mechanism used to overcome iron limitation [58]. However, siderophores are not sufficient for efficient iron scavenging, because these molecules need to be transported to the extracellular space and then the ironsiderophore complex back to the cell [59]. TonBdependent carriers together with $\mathrm{ABC}$-type transporters are crucial in iron transport. In our study, MPn treatment induced expression of TonB-dependent receptors and Fesiderophore transporters, as well as an AraC-type regulator, which has a role in the regulation of gene expression. No known siderophores were identified from the genome of $N$. spumigena UHCC 0039 . However, the strain carries a genetic region similar to Nostoc sp. PCC 7120, which has an important role in iron metabolism [60]. This particular gene cluster has also a great similarity to a siderophore-coding cluster in Agrobacterium tumefaciensis [61]. The gene cluster of this putative siderophore in N. spumigena UHCC 0039 was heavily upregulated in the MPn condition, but the product remained elusive in this study. Iron constitute cluster with sulfur in the active site of PhnJ [62] and enhanced production of PhnJ may thus cause demand of iron in the cells. In addition, phosphorus and iron are the major nutrients limiting the growth of diazotrophic cyanobacterial blooms during the summer in the Baltic Sea and co-regulation of the genes suggests a hardwired strategy to deal with nutrient limitation in N. spumigena.

\section{Conclusion}

Here we demonstrate that strains of $N$. spumigena can grow using methylphosphonate as a sole source of phosphorous with only minor remodeling of the transcriptome. Our results show that phn gene clusters are wide-spread in the genomes of the toxic bloom-forming $N$. spumigena. This particular genetic element may enable $N$. spumigena to cope with $\mathrm{P}_{\mathrm{i}}$-limited conditions by degrading phosphonates and liberating phosphate for the cellular usage. Alkaline phosphatase activity, a marker used to indicate $\mathrm{P}_{\mathrm{i}}$ starvation, was not detected from the culture growing in the medium supplemented by MPn but a transcriptional response of $p s t S$, the other molecular marker used for $\mathrm{P}_{\mathrm{i}}$ scarcity, was found. $N$. spumigena may contribute to methane supersaturation in the water column by degrading MPn to release phosphate and methane.

Acknowledgements We thank Lyudmila Saari for the maintenance of cyanobacterial culture collection and the crew on R/V Aranda (research vessel owned by the Finnish Environment Institute) for their kind assistance during the sampling cruise. This work resulted from the BONUS Blueprint project and was supported by BONUS (Art 185), funded jointly by the EU and Academy of Finland and Nordic Center of Excellence to KS. Bioinformatics analyses were supported by the German Federal Ministry for Education and Research (BMBF) program de.NBI-Partner (grant 031 L0106B) to WRH and by a China Scholarship Council grant to SWH.

\section{Compliance with ethical standards}

Conflict of interest The authors declare that they have no conflict of interest.

Open Access This article is licensed under a Creative Commons Attribution 4.0 International License, which permits use, sharing, adaptation, distribution and reproduction in any medium or format, as long as you give appropriate credit to the original author(s) and the source, provide a link to the Creative Commons license, and indicate if changes were made. The images or other third party material in this article are included in the article's Creative Commons license, unless indicated otherwise in a credit line to the material. If material is not included in the article's Creative Commons license and your intended use is not permitted by statutory regulation or exceeds the permitted use, you will need to obtain permission directly from the copyright holder. To view a copy of this license, visit http://creativecommons. org/licenses/by/4.0/.

\section{References}

1. Karl DM. Microbially mediated transformations of phosphorus in the sea: new views of an old cycle. Ann Rev Mar Sci. 2014;6:279-337.

2. Li H, Veldhuis MJW, Post AF. Alkaline phosphatase activities among planktonic communities in the northern Red Sea. Mar Ecol Prog Ser. 1998;173:107-15.

3. Nausch M. Alkaline phosphatase activities and the relationship to inorganic phosphate in the Pomeranian Bight (southern Baltic Sea). Aquat Microb Ecol. 1998;16:87-94.

4. Repeta DJ, Ferrón S, Sosa OA, Johnson CG, Repeta LD, Acker $\mathrm{M}$, et al. Marine methane paradox explained by bacterial degradation of dissolved organic matter. Nat Geosci. 2016;9:884-7.

5. Clark LL, Ingall ED, Benner R. Marine phosphorus is selectively remineralized. Nature. 1998;393:426. 
6. Young CL, Ingall ED. Marine dissolved organic phosphorus composition: insights from samples recovered using combined electrodialysis/reverse osmosis. Aquat Geochem. 2010;16:563-74.

7. Kononova SV, Nesmeyanova MA. Phosphonates and their degradation by microorganisms. Biochemistry. 2002;67:184-95.

8. Metcalf WW, Griffin BM, Cicchillo RM, Gao J, Janga SC, Cooke HA, et al. Synthesis of methylphosphonc acid by marine microbes: a source for methane in the aerobic ocean. Science. 2012;337:1104-7.

9. Dyhrman ST, Benitez-Nelson CR, Orchard ED, Haley ST, Pellechia PJ. A microbial source of phosphonates in oligotrophic marine systems. Nat Geosci. 2009;2:696-9.

10. Graneli E, Wallstrom K, Larsson U, Wilhelm G, Elmgren R. Nutrient limitation of primary production in the Baltic Sea Area. Ambio. 1990;19:142-51.

11. Ploug H, Adam B, Musat N, Kalvelage T, Lavik G, WolfGladrow D, et al. Carbon, nitrogen, and $\mathrm{O} 2$ fluxes associated with the cyanobacterium Nodularia spumigena in the Baltic Sea. ISME J. 2011;5:1549-58.

12. Sundareshwar JT, Morris EK, Koepfler B, Fornwalt PV. Phosphorus limitation of coastal ecosystem processes. Science. 2003;299:563-5.

13. Hirani TA, Suzuki I, Murata N, Hayashi H, Eaton-Rye JJ. Characterization of a two-component signal transduction system involved in the induction of alkaline phosphatase under phosphate-limiting conditions in Synechocystis sp. PCC 6803. Plant Mol Biol. 2001;45:133-44.

14. Suzuki S, Ferjani A, Suzuki I, Murata N. The SphS-SphR two component system is the exclusive sensor for the induction of gene expression in response to phosphate limitation in Synechocystis. J Biol Chem. 2004;279:13234-40.

15. Santos-Beneit F. The Pho regulon: a huge regulatory network in bacteria. Front Microbiol. 2015;6:402.

16. Su Z, Olman V, Xu Y. Computational prediction of Pho regulons in cyanobacteria. BMC Genom. 2007;8:156.

17. Yamada M, Makino K, Amemura M, Shinagawa H, Nakata A. Regulation of the phosphate regulon of Escherichia coli: analysis of mutant $p h o B$ and $p h o R$ genes causing different phenotypes. J Bacteriol. 1989;171:5601-6.

18. White AK, Metcalf WW. Microbial metabolism of reduced phosphorus compounds. Annu Rev Microbiol. 2007;61:379-400.

19. Cook AM, Daughton CG, Alexander M. Phosphonate utilization by bacteria. J Bacteriol. 1978;133:85-90.

20. Metcalf WW, Wanner BL. Involvement of the Escherichia coli phn ( $p s i D)$ gene cluster in assimilation of phosphorus in the form of phosphonates, phosphite, $\mathrm{P}_{\mathrm{i}}$ esters, and $\mathrm{P}_{\mathrm{i}}$. $\mathrm{J}$ Bacteriol. 1991;173:587-600.

21. Metcalf WW, Wanner BL. Mutational analysis of an Escherichia coli fourteen-gene operon for phosphonate degradation, using TnphoA' elements. J Bacteriol. 1993;175:3430-42.

22. White AK, Metcalf WW. Two C-P lyase operons in Pseudomonas stutzeri and their roles in the oxidation of phosphonates, phosphite, and hypophosphite. J Bacteriol. 2004;186:4730-9.

23. Kamat SS, Williams HJ, Raushel FM. Intermediates in the transformation of phosphonates to phosphate by bacteria. Nature. 2011;480:570-3.

24. Gebhard S, Cook GM. Differential regulation of high-affinity phosphate transport systems of Mycobacterium smegmatis: identification of PhnF, a repressor of the phnDCE operon. J Bacteriol. 2008;190:1335-43.

25. Adams MM, Gómez-García MR, Grossman AR, Bhaya D. Phosphorus deprivation responses and phosphonate utilization in a thermophilic Synechococcus sp. from microbial mats. J Bacteriol. 2008;190:8171-84.
26. Dyhrman ST, Chappell PD, Haley ST, Moffett JW, Orchard ED, Waterbury JB, Webb EA. Phosphonate utilization by the globally important marine diazotroph Trichodesmium. Nature. 2006;439:68-71.

27. Forlani G, Pavan M, Gramek M, Kafarski P, Lipok J. Biochemical bases for a widespread tolerance of cyanobacteria to the phosphonate herbicide glyphosate. Plant Cell Physiol. 2008:49:443-56.

28. Gomez-Garcia MR, Davison M, Blain-Hartnung M, Grossman AR, Bhaya D. Alternative pathways for phosphonate metabolism in thermophilic cyanobacteria from microbial mats. ISME J. 2011;5:141-9.

29. Karl DM, Beversdorf L, Björkman KM, Church MJ, Martinez A, Delong EF. Aerobic production of methane in the sea. Nat Geosci. 2008;1:473-8.

30. Koskenniemi K, Lyra C, Rajaniemi-Wacklin P, Jokela J, Sivonen K. Quantitative real-time PCR detection of toxic Nodularia cyanobacteria in the Baltic Sea. Appl Environ Microbiol. 2007;73:2173-9.

31. Repka S, Meyerhöfer M, von Bröckel K, Sivonen K. Associations of cyanobacterial toxin, nodularin, with environmental factors and zooplankton in the Baltic Sea. Microb Ecol. 2004; 47:350-8.

32. Sivonen K, Kononen K, Carmichael WW, Dahlem AM, Rinehart KL, Kiviranta J, Niemelä SI. Occurrence of the hepatotoxic cyanobacterium Nodularia spumigena in the Baltic Sea and structure of the toxin. Appl Environ Microbiol. 1989;55:1990-5.

33. Nausch M, Nausch G, Wasmund N. Phosphorus dynamics during the transition from nitrogen to phosphate limitation in the central Baltic Sea. Mar Ecol Prog Ser. 2004;266:15-25.

34. Olofsson M, Egardt J, Singh A, Ploug H. Inorganic phosphorus enrichments in Baltic Sea water have large effects on growth, Cand $\mathrm{N}_{2}$-fixation by Nodularia spumigena. Aquat Microb Ecol. 2016;77:111-23.

35. Vahtera E, Laamanen M, Rintala J-M. Use of different phosphorus sources by the bloom-forming cyanobacteria Aphanizomenon flos-aquae and Noularia spumigena. Aquat Microb Ecol. 2007;46:225-37.

36. Vo $\beta$ B, Bolhuis H, Fewer DP, Kopf M, Möke F, Haas F, et al. Insights into the physiology and ecology of the brackish-wateradapted cyanobacterium Nodularia spumigena CCY9414 based on a genome-transcriptome analysis. PLoS ONE. 2013;8: e60224.

37. Bange HW, Dahlke S, Ramesha R, Meyer-Reil L-A, Rapsomanikise S, Andreaea MO. Seasonal study of methane and nitrous oxide in the coastal waters of the Southern Baltic Sea. Estuar Coast Shelf Sci. 1998;47:807-17.

38. Bange HW, Bartell UH, Rapsomanikis S, Andreae MO. Methane in the Baltic and North Seas and a reassessment of the marine emissions of methane. Glob Biogeochem Cycles. 1994;8:465-80.

39. Rutherford K, Parkhill J, Crook J, Horsnell T, Rice P, Rajandream MA, Barrell B. Artemis: sequence visualization and annotation. Bioinformatics. 2000;16:994-5.

40. Kótai, J. Instructions for preparation of modified nutrient solution Z8 for algae. NIVA: Oslo, Norway; B-11/69; 1972.

41. Jeffrey SW, Humphrey GF. New spectrophotometric equations for determining chlorophylls a, b, c1 and c2 in higher plants, algae and natural phytoplankton. Biochem Physiol Pflanz. 1975;167:191-4.

42. Middelboe M, Søndergaard M, Letarte Y, Borch NH. Attached and free-living bacteria: production and polymer hydrolysis during a diatom bloom. Microb Ecol. 1995;29:231-48.

43. Penttilä A, Slade EM, Simojoki A, Riutta T, Minkkinen K, Roslin T. Quantifying beetle-mediated effects on gas fluxes from dung pats. PLoS ONE. 2013;8:e71454. 
44. Laudenbach DE, Straus NA. Characterization of a cyanobacterial iron stress-induced gene similar to $p s b C$. J Bacteriol. 1988;170:5018-26.

45. Burnap RL, Troyan T, Sherman LA. The highly abundant chlorophyll-protein complex of iron-deficient Synechococcus sp. PCC7942 (CP43') is encoded by the isiA gene. Plant Physiol. 1993;103:893-902.

46. Moisander PH, Paerl HW, Dyble J, Sivonen K. Phosphorus limitation and diel control of nitrogen-fixing cyanobacteria in the Baltic Sea. Mar Ecol Prog Ser. 2007;345:41-50.

47. Sivonen K, Halinen K, Sihvonen LM, Koskenniemi K, Sinkko H, Rantasärkkä $\mathrm{K}$, et al. Bacterial diversity and function in the Baltic Sea with an emphasis on cyanobacteria. Ambio. 2007;36:180-5.

48. opin RV, Rigonato J, Abreu VA, Andreote AP, Silveira SB, Odebrecht C, Fiore MF. Draft genome assembly of the bloomforming cyanobacterium Nodularia spumigena strain CENA596 in shrimp production ponds. Genome Announc. 2016;4: e00466-16.

49. Choi DH, Ryu J-Y, Kwon K-K, Lee J-H, Kim C, Lee CM, et al. Draft genome sequence of Rubidibacter lacunae strain KORDI 51-2T, a cyanobacterium isolated from seawater of Chuuk lagoon. Stand Genom Sci. 2013;9:197-204.

50. Villarreal-Chiu JF, Quinn JP, McGrath JW. The genes and enzymes of phosphonate metabolism by bacteria, and their distribution in the marine environment. Front Microbiol. 2012;3:19.

51. Feingersch R, Philosof A, Mejuch T, Glaser F, Alalouf O, Shoham Y, Béjà O. Potential for phosphite and phosphonate utilization by Prochlorococcus. ISME J. 2012;6:827-34.

52. Klawonn I, Nahar N, Walve J, Andersson B, Olofsson M, Svedén $\mathrm{JB}$, et al. Cell-specific $\mathrm{N}_{2}$-fixation and primary production by cyanobacteria in a temperate marine system (the Baltic Sea). Environ Microbiol. 2016;18:4596-609.

53. Moisander PH, Steppe TF, Hall NS, Kuparinen J, Paerl HW. Variability in nitrogen and phosphorus limitation for Baltic Sea phytoplankton during nitrogen-fixing cyanobacterial blooms. Mar Ecol Prog Ser. 2003;262:81-95.

54. Conley DJ, Paerl HW, Howarth RW, Boesch DF, Seitzinger SO, Havens KE, et al. Controlling eutrophication: nitrogen and phosphorus. Science. 2009;323:1014-5.

55. Skeff W, Neumann C, Schulz-Bull DE. Glyphosate and AMPA in the estuaries of the Baltic Sea method optimization and field study. Mar Poll Bull. 2015;100:577-85.

56. Ploug H. Cyanobacterial aggregates formed by Aphanizomenon sp. and Nodularia spumigena in the Baltic Sea: small-scale fluxes, $\mathrm{pH}$ and oxygen microenvironments. Limnol Oceanogr. 2008;53:914-21.

57. Ludwig M, Bryant DA. Synechococcus sp. strain PCC 7002 transcriptome: Acclimation to temperature, salinity, oxidative stress, and mixotrophic growth conditions. Front Microbiol 2012;3:354.

58. Simpson FB, Neilands JB. Siderochromes in cyanophyceae: isolation and characterization of schizokinen from Anabaena sp. J Phycol. 1976;12:44-48.

59. Stevanovic M, Hahn A, Nicolaisen K, Mirus O, Schleiff E. The components of the putative iron transport system in the cyanobacterium Anabaena sp. PCC 7120. Environ Microbiol. 2012;14:1655-70.

60. Jeanjean R, Talla E, Latifi A, Havaux M, Janicki A, Zhang CC. A large gene cluster encoding peptide synthetases and polyketide synthases is involved in production of siderophores and oxidative stress response in the cyanobacterium Anabaena sp. strain PCC 7120. Environ Microbiol. 2008;10:2574-85.

61. Rondon MR, Ballering KS, Thomas MG. Identification and analysis of a siderophore biosynthetic gene cluster from Agrobacterium tumefaciens C58. Microbiology. 2004; 150:3857-66.

62. Seweryn P, Van LB, Kjeldgaard M, Russo CJ, Passmore LA, Hove-Jensen B, et al. Structural insights into the bacterial carbonphosphorus lyase machinery. Nature 2015;525:68-72. 